\title{
Differential effect of thyroid-stimulating hormone (TSH) on intracellular free calcium and cAMP in cells transfected with the human TSH receptor
}

\author{
R A Metcalfe, C Findlay, W R Robertson ${ }^{1}$, A P Weetman and \\ S Mac Neil
}

University of Sheffield, Department of Medicine, Clinical Sciences Centre, Northern General Hospital, Sheffield S5 7AU, UK and ${ }^{1}$ Department of Medicine, Section of Clinical Biochemistry, Hope Hospital, Eccles Old Road, Salford M6 8HD, UK

(Requests for offprints should be addressed to S Mac Neil)

\begin{abstract}
The thyroid-stimulating hormone (TSH) binds to a receptor which activates adenylate cyclase and elevates cAMP concentration. In addition, effects of TSH on intracellular calcium and inositol phosphate accumulation have been reported. However, the mechanism of TSH-stimulated accumulation of inositol phosphates and elevation of calcium levels is unresolved. Previous work from this laboratory has shown TSH to cause acute transient increases in intracellular calcium in pig, human and FRTL-5 rat thyroid cells as well as in cells transfected with the human TSH receptor (JPO9 cells) in some (but not all) experiments. The aim of this study was to investigate the variability of the calcium response to TSH in JPO9 cells to learn more about the nature of this calcium signal induction. Calcium responses to TSH were determined using the fluorochrome fura-2 in both monolayers of adherent cells and adherent single cells. The responses to a single addition and to repetitive additions of TSH were compared. We also determined the cAMP response to TSH using these two protocols of TSH addition.

Our data show that, whereas the cAMP response to TSH is highly predictable and consistent and does not
\end{abstract}

require multiple exposures to $\mathrm{TSH}$, cells were unlikely to respond to TSH with an increase in calcium unless they received multiple challenges with the hormone. A single addition of $10 \mathrm{mU} / \mathrm{ml} \mathrm{TSH}$ failed to increase calcium in any of 40 single cells examined and in only 4 of 15 monolayers of cells (27\%) examined; in contrast, 10 of 12 monolayers eventually responded with an increase in calcium after multiple exposure to TSH and 18 of 67 single cells. Similar data were obtained whether calcium was measured in single cells or in populations of cells. We also demonstrated cooperativity between an adenosine derivative, $N^{6}$-(L-2-phenylisopropyl)adenosine, and TSH such that their co-administration resulted in a consistent and marked elevation in calcium levels not achieved with either agonist alone. In summary, we suggest that the coupling between the TSH receptor and the intracellular signalling system that leads to activation of intracellular calcium in JPO9 cells requires repetitive stimulation or the influence of other agonists, in contrast with the coupling between the TSH receptor and activation of the adenylate cyclase enzyme.

Journal of Endocrinology (1998) 157, 415-424

\section{Introduction}

Thyroid-stimulating hormone (TSH)-stimulated increases in intracellular cAMP are well established and account for most of the biological actions of TSH in thyroid cells. A few actions of TSH appear to be cAMP-independent, e.g. iodide efflux in FRTL-5 cells which appears to be calcium-dependent (Weiss et al. 1984), stimulation of growth in human thyroid cells (Dumont et al. 1992) and induction of desensitisation (Shuman et al. 1976). However, the mechanism of TSH action on other intracellular signalling systems is unresolved despite a large number of studies over several decades (e.g. Scott et al. 1970) showing that TSH preparations will cause an accumulation of inositol polyphosphates and, more recently, that it will also increase intracellular calcium in a range of thyroid cells (e.g. dog (Rani et al. 1985), rat FRTL-5 cells (Corda et al. 1985, Mac Neil et al. 1994, Singh et al. 1996), pig (Takasu et al. 1986, Ye et al. 1991), CHO cells transfected with the human TSH receptor (Van Sande et al. 1990, Mac Neil et al. 1994) and human thyroid cells (Mac Neil et al. 1994, Singh et al. 1996)). A recent study shows that the effects of TSH on inositol phosphate and calcium do not fit the classical pattern of agonists activating phospholipase C (Singh et al. 1996), leaving unresolved the nature of this TSH-induced signalling. 
Details of the mechanism of these cAMP-independent actions of TSH are irrelevant unless these actions are part of TSH physiology. We suggest that actions of TSH on intracellular calcium will prove to be of relevance to TSH biology primarily because human TSH-stimulated adenylate cyclase activity is itself regulated by calcium and calmodulin (Lakey et al. 1985). The response of this enzyme to calcium is biphasic, with submicromolar concentrations of calcium (as would be found in the resting cell) required for maximum responsiveness of the enzyme to TSH and higher, micromolar, concentrations (as would be found in the stimulated cell) inhibiting TSH-stimulated adenylate cyclase activity. Such micromolar concentrations of calcium would also activate the calcium/calmodulindependent phosphodiesterase, a rise in calcium tending to both inhibit the generation of cAMP and increase its breakdown (as discussed in Mac Neil et al. 1985). Thus an increase in intracellular calcium would tend to reduce or terminate the TSH-stimulated cAMP signal. Incubation of pig thyroid cells with TSH for 3 days increases intracellular calmodulin (Takasu et al. 1988, Ye et al. 1991), and acute addition of TSH to these cells causes a transient increase in calcium in around 70-80\% of cells (Ye et al. 1991).

Another finding that leads us to conclude that inositol phosphate turnover in response to TSH stimulation may 'cross-talk' with TSH-stimulated cAMP accumulation stems from our studies with lithium in thyroid cells. In patients receiving lithium for manic depression, TSH resistance commonly develops (e.g. Lazarus et al. 1981). Lithium has been found to inhibit TSH-stimulated thyroid hormone release from thyroid tissue in vitro (Williams et al. 1971, Mori et al. 1989). Lithium-induced resistance to TSH can be demonstrated in pig thyroid cells where $1 \mathrm{mM}$ inhibits TSH-stimulated cAMP accumulation within 30 min (Wragg \& Mac Neil 1991). Examination of the effect of lithium on the TSH-stimulated adenylate cyclase failed to reveal any direct effect of this ion on the enzyme; lithium-induced TSH resistance was only demonstrable in intact cells. Lithium is a known potent inhibitor of several inositol phosphatases (see e.g. Berridge et al. 1992). One explanation for these data (as proposed in Mac Neil et al. 1993) is that lithium, through inhibiton of inositol phosphatases, affects inositol phosphate turnover which, in turn, affects intracellular free calcium, leading to inhibition of TSH-stimulated adenylate cyclase activity.

However, a major practical problem in investigating the physiological significance of TSH-induced increases in intracellular calcium is the lack of reproducibility of this response to TSH, as shown for pig (Ye et al. 1991), human, rat FRTL-5 thyroid cells and eukaryotic cells transfected with the human TSH receptor (Mac Neil et al. 1994). The highest frequency of thyroid cells responding to TSH with an increase in calcium was achieved with pig thyroid cells where 114 of $147(77 \%)$ of subconfluent cultures of cells responded to $10 \mathrm{mU} / \mathrm{ml} \mathrm{TSH} \mathrm{(Ye} \mathrm{et} \mathrm{al.} \mathrm{1991).} \mathrm{Responses}$ were less consistent in confluent cultures of pig cells. The response to $10 \mathrm{mU} / \mathrm{ml} \mathrm{TSH}$ was only $22 \%$ in human thyroid cells, 22\% in rat FR TL-5 cells and 46\% in Chinese hamster ovary cells transfected with the human TSH receptor. In contrast, 18 of 25 (72\%) Graves' IgG preparations increased calcium in these cells at relatively low concentrations $(0.1 \mathrm{mg} / \mathrm{ml})$, whereas much higher concentrations $(1-3 \mathrm{mg} / \mathrm{ml})$ were required to produce a significant elevation in cAMP levels. We concluded that relatively low concentrations of patient IgGs could be distinguished from control IgGs in JPO9 cells on the basis of their ability to increase calcium (Mac Neil et al. 1994).

The objective of the current study was to address the problem of the poor reproducibility of the calcium response to TSH in order to obtain further information on the nature of this signalling and aid future studies. We explored two approaches to improve the reproducibility of the calcium response. First, we examined whether TSHstimulated calcium increases can be detected more readily using single-cell calcium analysis than analysis of unsynchronised monolayers of cells, in which a small increase in calcium occurring in some cells but not others might not generate sufficient signal to be detected. We also examined the impact of multiple exposures to TSH on both the cAMP and calcium responses. Throughout, we used JPO9 $\mathrm{CHO}$ cells transfected with the human TSH receptor, which respond to TSH with an increase in calcium whereas control transfected cells do not (Mac Neil et al. 1994). We also examined whether any cooperativity exists between the adenosine and the TSH receptor with respect to calcium signalling as has been reported for human thyroid cells (Yanagita et al. 1996).

We report that TSH reproducibly gives an increase in cAMP in cells after single or multiple additions of hormone; in contrast, an increase in calcium is much more likely to be seen in cells that have received multiple exposures of TSH than in those receiving a single addition of TSH. Similar results were obtained whether calcium was determined in populations of cells or in single cells. We also demonstrate that an adenosine derivative shows cooperativity with TSH in inducing an increase in calcium in JPO9 cells.

\section{Materials and Methods}

\section{Materials}

Coon's modified Ham's F12 medium, PBS (without calcium or magnesium), Hanks balanced salt solution, penicillin, amphotericin $\mathrm{B}$, trypsin-EDTA $(0.5 \mathrm{~g}$ trypsin and $0.2 \mathrm{~g}$ EDTA per litre of modified Puck's saline A), fungizone, L-glutamine and foetal calf serum were obtained from Life Technologies, Paisley, UK. Fura2-AM was obtained from Molecular Probes Inc., Cambridge Biosciences, Cambridge, MA, USA. For the majority of studies, the TSH used was bovine thyrotrophin (pituitary TSH), for bioassay, 1st International Standard 
(74 milli-International Units/mg; batch 53/11) from the National Institute for Biological Standards and Control, Holly Hill, London, UK. Some investigations used recombinant human (rh) TSH from Genzyme Diagnostics, Kent, UK.

The adenosine derivative $N^{6}$-(L-2-phenylisopropyl)adenosine (PIA) was obtained from Sigma.

\section{CHO cell culture}

Clones of $\mathrm{CHO}$ cells expressing the human TSH receptor and a resistance gene to neomycin (JPO9) and $\mathrm{CHO}$ cells expressing only a neomycin-resistance gene (JPO2) were kindly given by Professor J E Dumont, Free University of Brussels, Brussels, Belgium. Cells were cultured in Ham's F12 medium with 10\% foetal calf serum, $2 \mathrm{mmol} / 1$ L-glutamine, $0.625 \mu \mathrm{g} / \mathrm{ml}$ fungizone and $40 \mu \mathrm{g} / \mathrm{ml}$ Geneticin.

\section{cAMP assay}

Intracellular cAMP accumulation was determined using tritiated adenine labelling of the nucleotide pool. Cells were exposed to $\mathrm{TSH}$ at $37^{\circ} \mathrm{C}$ as previously described (Michelangeli et al. 1994) except that tritiated cAMP was separated from other nucleotides using neutral alumina chromatography alone rather than a combination of ionexchange chromatography and neutral alumina chromatography as used by Michelangeli et al. (1994). All determinations were performed in triplicate.

\section{Intracellular calcium measurement in monolayers of cells}

Fura-2 dye was used to determine intracellular calcium in monolayers of cells cultured on glass coverslips using a Kontron SFM 25 fluorimeter (Kontron Instruments Ltd, Watford, Herts, UK) as previously described for pig thyroid cells (Ye et al. 1991). Monolayers of cells (used at around $80 \%$ confluence by eye) were incubated with $4 \mu \mathrm{M}$ fura-2-AM for $15 \mathrm{~min}$ at $37^{\circ} \mathrm{C}$ in a $\mathrm{CO}_{2}$ incubator. The coverslips were then rinsed twice in balanced salt solution (BSS; $135 \mathrm{mmol} / \mathrm{l} \mathrm{NaCl}, 4.5 \mathrm{mmol} / \mathrm{l} \mathrm{KCl}$, $1.5 \mathrm{mmol} / 1 \mathrm{CaCl}_{2}, 0.5 \mathrm{mmol} / \mathrm{MgCl}_{2}, 5.6 \mathrm{mmol} / 1 \mathrm{glu}-$ cose and $10 \mathrm{mmol} / 1$ Hepes, $\mathrm{pH} 7 \cdot 4$, in distilled deionised water) to remove any unloaded dye. The coverslips (which had previously been cut to the exact size using a diamond knife) were placed across the diagonal of a $1 \mathrm{~cm}$ quartz cuvette and supported on a plastic bridge within the cuvette which allowed a small magnetic stirrer bar to be used to give a continuous mixing of the cuvette contents.

All coverslips were checked for evidence of dye loading before investigation and were exposed to ionomycin and $\mathrm{MnCl}_{2}$, at the end of each experiment, to verify that the dye that had been loaded was accessible to changes in cytosolic calcium. Changes in intracellular fluorescence versus time were recorded using a fixed excitation wave- length of $335 \mathrm{~nm}$, recording fluorescence emission at $490 \mathrm{~nm}$. Once a stable baseline of fluorescence was obtained, acute bolus additions of BSS or TSH were made. In all cases, additions represented no more than $1-2 \%$ of the cuvette contents $(3 \mathrm{ml})$.

Qualitative rather than quantitative assessment of changes in intracellular calcium was used throughout this study because of the variable and transient nature of most of the responses seen; examples of the range of responses are given in the Results. All coverslips were also exposed to equivalent volumes of BSS to determine the 'noise' level of each experiment, which was taken into consideration in interpreting the data.

\section{Measurement of intracellular calcium in single cells}

Monolayers of cells were cultured for up to 4 days on $24 \mathrm{~mm}$ diameter circular glass coverslips (Chance Propper Ltd, Smethwick, UK) before loading with fura-2-AM $(4 \mu \mathrm{M})$ for up to $1 \mathrm{~h}$. After dye loading, the cells were washed twice with BSS and then a coverslip was placed in an open perfusion chamber which was attached to a Nikon Diaphot fluorescent microscope. Then $2 \mathrm{ml}$ BSS was gently introduced on to the coverslip, and a suitable group of cells identified using transmission phase-contrast microscopy. The excitation filters used for fura- 2 were 340 and $380 \mathrm{~nm}$ and they were held in a filter changer wheel, which could move between positions at a maximum speed of $25 \mathrm{~ms}$. Heat filters were used to protect the surfaces of the excitation filters, and neutral density filters were used to reduce photobleaching of the dyes and photodamage to the cells by attenuating the light by at least $95 \%$ for all filters. A dichroic mirror allowed light below $515 \mathrm{~nm}$ to be deflected down on to the specimen and light above this wavelength to be transmitted to the camera. A further barrier filter ensured that light emitted from the cells was collected between 520 and $600 \mathrm{~nm}$. All experiments were performed at room temperature and images were collected for up to $25 \mathrm{~min}$. After the capture of images from cells held in BSS, the incubation medium was changed at set intervals $(5 \mathrm{~min})$ by replacing it with BSS containing either TSH $(0 \cdot 01-10 \mathrm{mU} / \mathrm{ml})$ or ATP $(1 \mathrm{mM})$. The effect of medium aspiration/addition on intracellular calcium was also studied within each set of experiments by changing the medium with fresh BSS alone. Cellular fluorescence was captured with an extended ISIS camera (Photonic Science Ltd, Robertsbridge, East Sussex, UK) every $5 \mathrm{~min}$ after alternate excitation at 340 and $380 \mathrm{~nm}$. The final image was produced from video rate averaging of between two and five images, each of which was collected as a pixel array (up to a maximum of $560 \times 512$ pixels), with each pixel being allocated a grey level (0-255). Each pixel digital image was then pseudocoloured and held on the computer hard disc. Autofluorescence due to the glass and medium was always less than $10 \%$ of the total signal. After definition of the cell by 
Table 1 Effect of single and repetitive additions of TSH on intracellular calcium in JPO9 cells

\begin{tabular}{|c|c|c|c|}
\hline & & \multicolumn{2}{|l|}{$\begin{array}{l}\text { Frequency of agonist } \\
\text { increasing calcium }\end{array}$} \\
\hline & & Monolayers of cells & Single cells \\
\hline \multicolumn{4}{|c|}{ Single addition protocol } \\
\hline ATP (1 mM) & & $13 / 18(72)$ & $31 / 39(79$ \\
\hline $\mathrm{TSH}(10 \mathrm{mU} / \mathrm{r}$ & & $4 / 15(27)$ & $0 / 40(0)$ \\
\hline \multicolumn{4}{|c|}{$\begin{array}{l}\text { Sequential addition } \\
\text { protocol }\end{array}$} \\
\hline \multirow[t]{7}{*}{$\mathrm{TSH}(\mathrm{mU} / \mathrm{ml})$} & $0 \cdot 01$ & Not done & $0 / 67(0)$ \\
\hline & $0 \cdot 1$ & $1 / 12(8)$ & $0 / 67(0)$ \\
\hline & 1 & $1 / 12(8)$ & $17 / 67(25$ \\
\hline & 10 & $3 / 12(25)$ & $18 / 67(27$ \\
\hline & 10 & $5 / 12(42)$ & Not done \\
\hline & 10 & $8 / 12(67)$ & Not done \\
\hline & 10 & 10/12 (83) & Not done \\
\hline
\end{tabular}

The data shown are numbers of monolayers and numbers of single cells (with percentages in parentheses)

pixel thresholding techniques, individual images were amended for autofluorescence and ratioed on a pixel basis to form the 340/380 ratio image. Data collection, ratioing of images and data analysis were performed by customdesigned software (Ionvision, available from Improvision Ltd, Viscount Venture Centre III, University of Warwick Science Park, Coventry, UK) and an Apple Quadra computer. The software allowed measurement within groups of cells, single cells or regions within a cell in sequential images.

\section{Statistics}

Differences between detection rates were assessed for significance using $\chi^{2}$ analysis.

\section{Results}

Effect of single and repetitive challenge with TSH on intracellular calcium in populations of cells

Addition of ATP to monolayers of JPO9 cells produced a clear increase in calcium in 13 of 18 experiments (72\%) as summarised in Table 1 and illustrated in Fig. 1.

When monolayers of JPO9 cells were challenged with $10 \mathrm{mU} / \mathrm{ml} \mathrm{TSH}$ and followed for periods of up to $15 \mathrm{~min}$, an increase in calcium was seen in only 4 of 15 experiments (27\%). Figure 2 illustrates two examples of populations of cells failing to respond to a single challenge with $10 \mathrm{mU} / \mathrm{ml} \mathrm{TSH}$. When cells were given a protocol of sequential additions of $\operatorname{TSH}(0 \cdot 1,1,10 \mathrm{mU} / \mathrm{ml})$, we observed transient increases in calcium on repeat challenge in $83 \%$ of experiments (10 of 12). This frequency is significantly higher than that seen after a single addition of

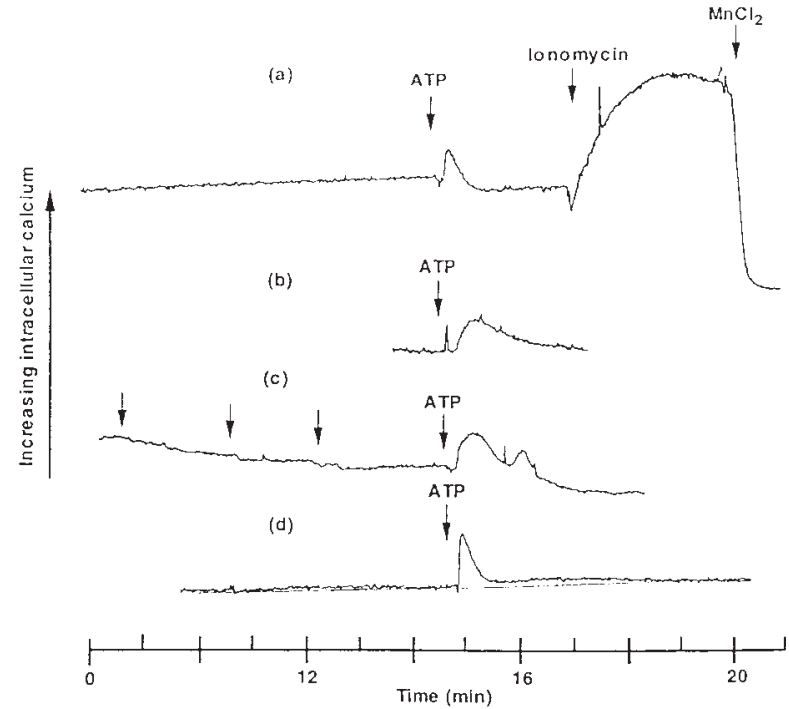

Figure 1 Effect of ATP $(1 \mathrm{mM})$ on intracellular calcium in monolayers of JPO9 cells. The figure illustrates four examples of monolayers of cells to which ATP was added as a single addition as indicated. In (c) the first three arrows indicate points of addition of BSS $(30 \mu \mathrm{l})$ (to which there was no response). Calibration of the coverslips using ionomycin and $\mathrm{MnCl}_{2}$ is illustrated in (a). Data summarising all such responses to ATP are shown in Table 1.

$10 \mathrm{mU} / \mathrm{ml}$ TSH in these cells (4 of 15 experiments, $P<0 \cdot 01)$. Figure 3 illustrates examples of three coverslips of cells in which increases in calcium occurred after sequential addition of TSH.

Table 1 summarises the responses to single additions of TSH and ATP (where cells are significantly less likely to respond to TSH than to ATP, $P<0 \cdot 05)$ and to sequential additions of TSH in these experiments in unsynchronised JPO9 cells. The frequency of cells responding to sequential additions of TSH (83\%) is not significantly different from that seen for cells responding to ATP $(72 \%)$.

\section{Effect of single and repetitive challenge with TSH on intracellular calcium in single cells}

Figure 4 illustrates the response of cells to a single addition of ATP. Data on the frequency of cells responding to agonists are shown in Table 1.

Figure $5 \mathrm{a}, \mathrm{b}$ and $\mathrm{c}$ illustrates the lack of response to a single addition of $10 \mathrm{mU} / \mathrm{ml} \mathrm{TSH}$ in individual JPO9 cells, followed for a period of at least $15 \mathrm{~min}$ after TSH addition. In contrast, when cells were subjected to a protocol of sequential additions of increasing concentrations of TSH $(0 \cdot 01,0 \cdot 1,1$ and $10 \mathrm{mU} / \mathrm{ml}$ at $5 \mathrm{~min}$ intervals), increases in calcium were seen in three of eight experiments, corresponding to a total of 18 of 67 cells responding $(27 \%)$. However, it was noticeable that, even in those cells that responded to TSH, not all cells within a cluster responded. In one experiment (Fig. 5d), only two 
(a)

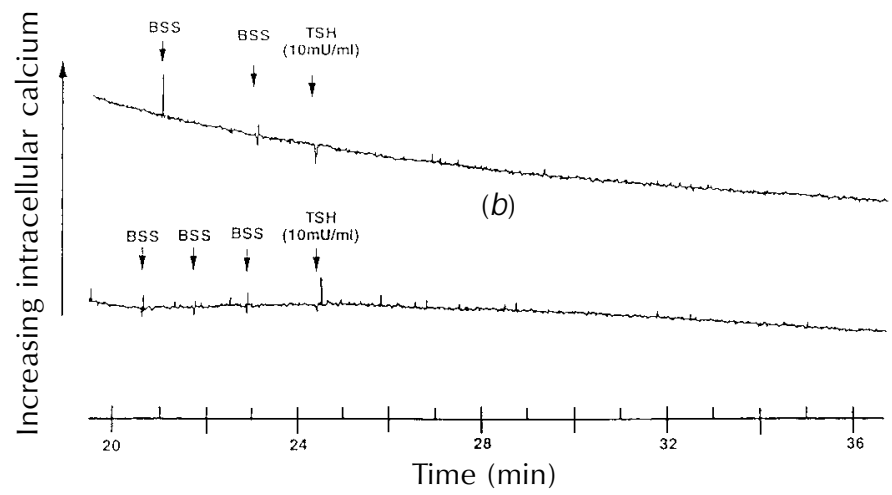

Figure 2 Effect of acute addition of $10 \mathrm{mU} / \mathrm{ml} \mathrm{TSH}$ on intracellular calcium in monolayers of cells. Two examples are shown of monolayers of cells acutely exposed to $10 \mathrm{mU} / \mathrm{ml}$ TSH. Coverslips were previously given equivalent-volume $(30 \mu \mathrm{l})$ additions of BSS. As can be seen in these examples, $\mathrm{TSH}$ failed to elicit an increase in calcium. Data summarising the response to single additions of TSH are given in Table 1.

(a)

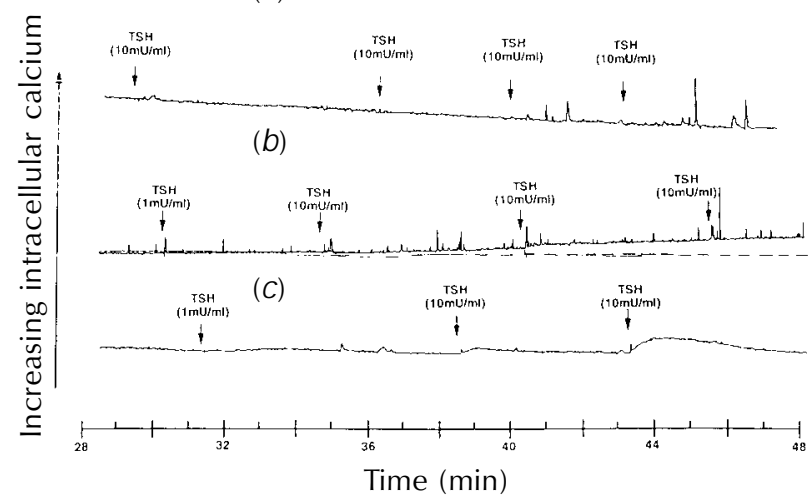

Figure 3 Effect of multiple additions of TSH on intracellular calcium in monolayers of cells. The figure shows three monolayers of cells which were given repeated additions of TSH at the concentrations indicated. Occasionally (as shown in c), the response to TSH gave a sustained increase in calcium (as shown in response to the third addition of TSH for this trace). More commonly, responses to the addition of TSH were a series of transient spikes in these unsynchronised cell populations as depicted in (a) and (b). Data summarising the response to multiple additions of TSH are given in Table 1.

of seven cells responded to TSH $(1 \mathrm{mU} / \mathrm{ml})$ with an increase in calcium whereas in the other two experiments, the majority of cells responded to TSH (five of seven cells shown in Fig. 5e responded to $1 \mathrm{mU} / \mathrm{ml} \mathrm{TSH}$ and then another of the remaining two cells responded to $10 \mathrm{mU} /$ $\mathrm{ml} \mathrm{TSH}$, and in Fig. 5f, all seven cells responded to $1 \mathrm{mU} / \mathrm{ml} \mathrm{TSH}$ ).

The frequency of cells responding to single or repetitive challenges with TSH is summarised in Table 1 where it can be seen that cells are significantly more likely (18 of 67

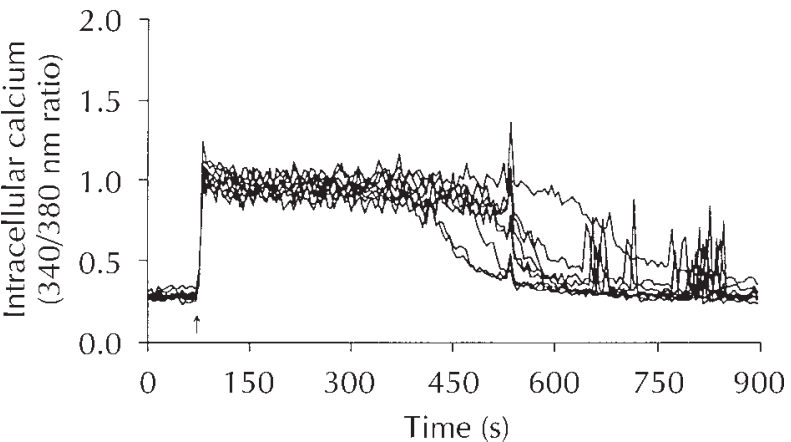

Figure 4 Effect of ATP on intracellular calcium in single JPO9 cells. A single addition of ATP $(1 \mathrm{mM})$ was given at the points indicated by the arrows. All cells responded to ATP with an immediate increase in calcium.

cells) to respond to multiple additions of TSH than to single additions ( 0 of 40 cells, $P<0 \cdot 05$ ).

Comparing the duration of the calcium level elevation in response to ATP with that seen to TSH, where it occurred, responses to ATP averaged around 5 min duration (as shown in Fig. 4), whereas responses to TSH tended to be brief: on only one occasion (out of a total of 18) did the response last for $5 \mathrm{~min}$. The majority of responses lasted for between $15 \mathrm{~s}$ and $2 \mathrm{~min}$.

\section{Effect of an adenosine derivative on TSH-stimulated intracellular calcium in populations of cells}

Following a recent study on human thyroid cells showing that the calcium response to TSH was increased after the addition of the adenosine derivative PIA, we examined the effect of PIA alone and in combination with bovine and recombinant human TSH (rhTSH) in populations of cells. 

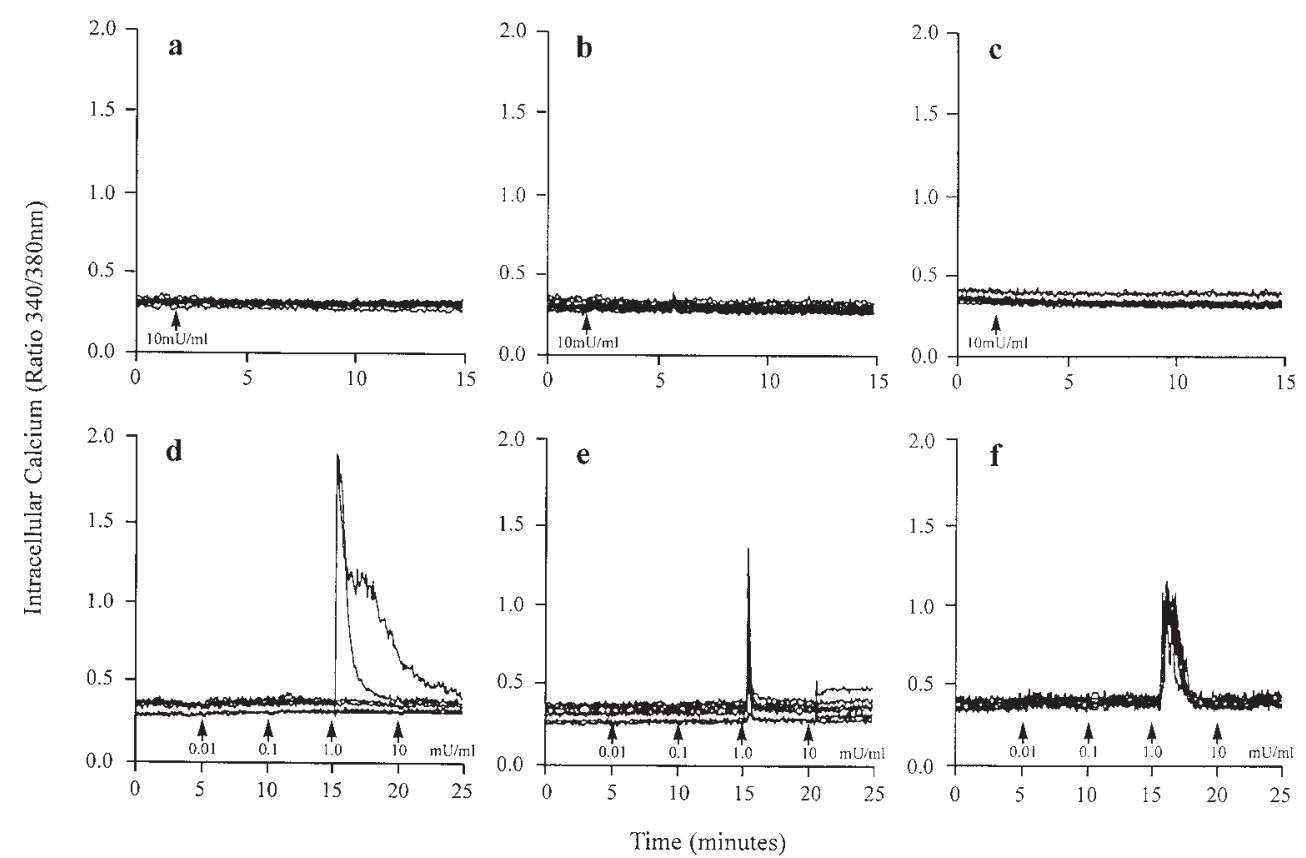

Figure 5 Comparison of the effect of single addition versus repetitive addition of TSH on intracellular calcium in JPO9 cells. In the three experiments illustrated in $(\mathrm{a}-\mathrm{c})$, cells were given $10 \mathrm{mU} / \mathrm{ml} \mathrm{TSH}$ at the point indicated by the arrow. In the experiments depicted in $(\mathrm{d}-\mathrm{f})$, the cells were given $0 \cdot 01,0 \cdot 1,1$ and $10 \mathrm{mU} / \mathrm{ml} \mathrm{TSH}$ at $5 \mathrm{~min}$ intervals at the points indicated by the arrows. In the experiment depicted in (d), only two of seven cells responded to $1 \mathrm{mU} / \mathrm{ml} \mathrm{TSH}$ with an increase in calcium. In the experiment depicted in (e), five of seven cells responded to $1 \mathrm{mU} / \mathrm{ml} \mathrm{TSH}$ with an increase in calcium and then a further cell responded to $10 \mathrm{mU} / \mathrm{ml} \mathrm{TSH}$. In the experiment depicted in (f), seven of seven cells responded with an increase in calcium.

The results are summarised in Table 2, and examples of responses are illustrated in Fig. 6.

Essentially, JPO9 cells showed very little calcium response to PIA alone (two of nine coverslips of cells responded with a

Table 2 Effect of adensoine receptor activation on calcium response to $\mathrm{TSH}$

\begin{tabular}{lll} 
Bovine TSH $(10 \mathrm{mU} / \mathrm{ml})$ & $5 / 10$ & $(50)$ \\
PIA $(1 \mu \mathrm{M})$ & $0 / 3$ & $(0)$ \\
$(10 \mu \mathrm{M})$ & $2 / 9$ & $(22)$ \\
*PIA $(10 \mu \mathrm{M})$ then bTSH $(1 \mathrm{mU} / \mathrm{ml})$ & $0 / 4$ & $(0)$ \\
*PIA $(10 \mu \mathrm{M})$ then bTSH $(10 \mathrm{mU} / \mathrm{ml})$ & $7 / 7$ & $(100)$ \\
†PIA $(10 \mu \mathrm{M})$ plus bTSH $(10 \mathrm{mU} / \mathrm{ml})$ & $11 / 11$ & $(100)$ \\
rhTSH $(10 \mu \mathrm{U} / \mathrm{ml})$ & $0 / 4$ & $(0)$ \\
$(100 \mu \mathrm{U} / \mathrm{ml})$ & $0 / 6$ & $(0)$ \\
$\quad(1 \mathrm{mU} / \mathrm{ml})$ & $0 / 8$ & $(0)$ \\
*PIA $(10 \mu \mathrm{M})$ then rhTSH $(10 \mu \mathrm{M} / \mathrm{ml})$ & $0 / 4$ & $(0)$ \\
& $0 / 4$ & $(0)$ \\
†PIA $(10 \mu \mathrm{M})$ plus rhTSH $(1 \mathrm{mU} / \mathrm{ml})$ & $0 / 3$ & $(0)$ \\
†PIA $(10 \mu \mathrm{M})$ plus rhTSH $(10 \mathrm{mU} / \mathrm{ml})$ & $3 / 3$ & $(100)$ \\
\cline { 2 - 3 } & &
\end{tabular}

The data shown are numbers of monolayers with percentages in parentheses.

*PIA was added approximately 5-10 min in advance of TSH.

†PIA and TSH were added simultaneously. modest and very transient increase in calcium to $10 \mu \mathrm{M}$ PIA as summarised in Table 2 and illustrated in Fig. 6a). As in earlier experiments, addition of a $10 \mathrm{mU} / \mathrm{ml}$ TSH alone gave a transient increase in some (five of ten) coverslips of cells (Fig. 6a). rhTSH from $10 \mu \mathrm{U} / \mathrm{ml}$ to $1 \mathrm{mU} / \mathrm{ml}$ failed to produce any convincing increase in calcium (Table 2 and Fig. 6e). However, when we challenged cells with PIA before $\mathrm{TSH}$, the response to $10 \mathrm{mU} / \mathrm{ml}$ bovine TSH increased to $100 \%$ (seven of seven monolayers), although there was still no response to rhTSH (Table 2).

Simultaneous addition of PIA $(10 \mu \mathrm{M})$ and TSH $(10 \mathrm{mU} / \mathrm{ml})$, however, gave a clear and more sustained increase in calcium in 11 of 11 monolayers (Table 2, Fig. 6a-e). We also saw a clear (albeit modest) calcium response to rhTSH when PIA $(10 \mu \mathrm{M})$ was added at the same time (Table 2, Fig. 6e).

\section{Effect of TSH on intracellular cAMP after single and repetitive challenge with $\mathrm{TSH}$}

Figure 7 illustrates the combined data of four experiments in which TSH was added either as sequential additions (Fig. 7a) or as one addition of $10 \mathrm{mU} / \mathrm{ml}$ (Fig. 7b). As can be seen, there was a clear increase in cAMP accumulation under both protocols. After a single addition of $10 \mathrm{mU} / \mathrm{ml}$ 


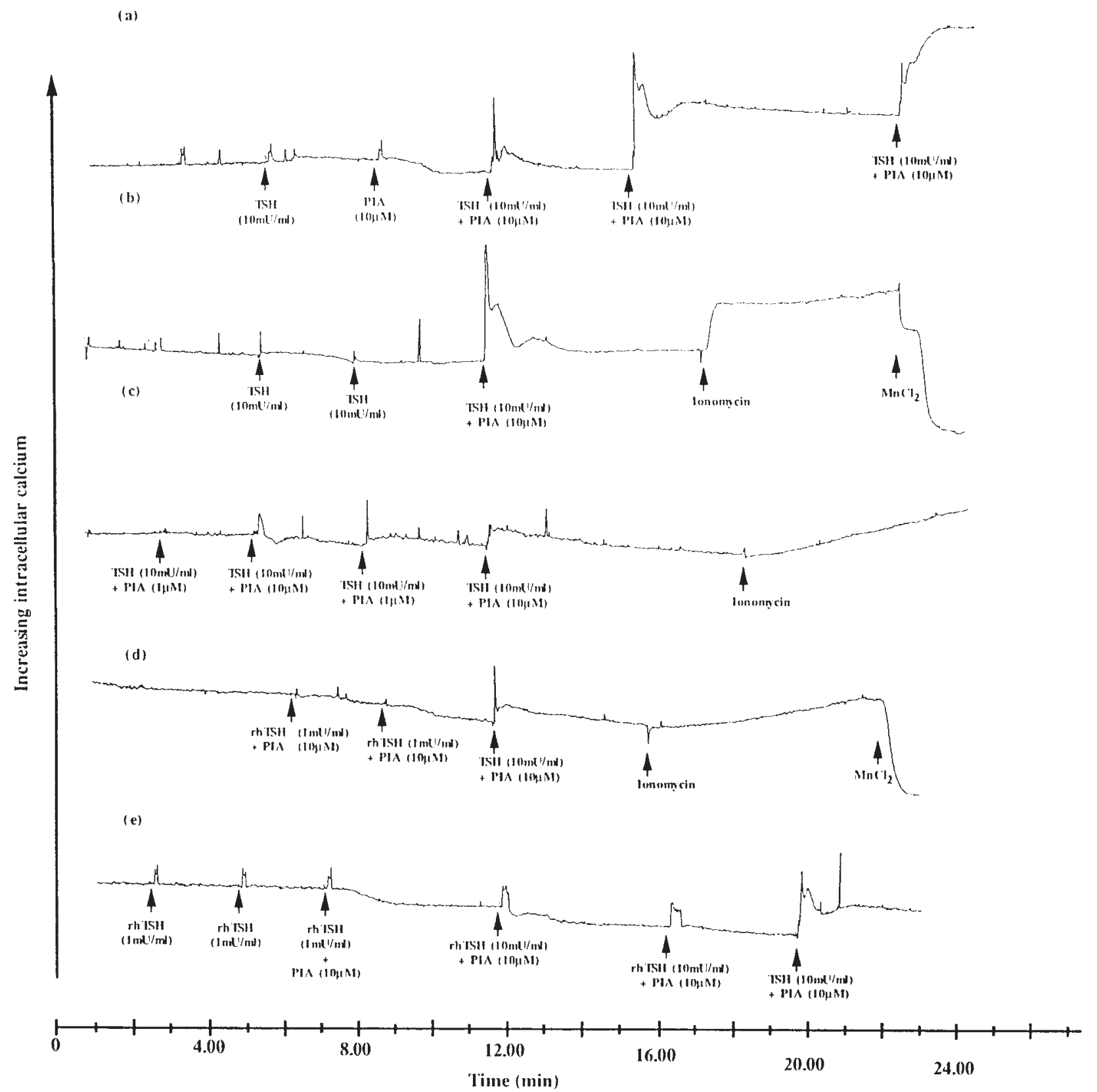

Figure 6 Effect of adenosine derivative PIA on ability of bovine (TSH) and recombinant human (rhTSH) TSH to elevate calcium concentration in monolayers of cells. Data summarising all responses are given in Table 2. As seen in (a) calcium responses to $10 \mathrm{mU} / \mathrm{ml}$ TSH and $10 \mu \mathrm{M}$ PIA on their own were modest, but the combined effect of $10 \mathrm{mU} / \mathrm{ml} \mathrm{TSH}$ and $10 \mu \mathrm{M}$ PIA was clearly greater than that achieved for either agonist alone. In (d) and (e), rhTSH alone had little or no effect on calcium; however, when $1 \mathrm{mU} / \mathrm{ml}$ rhTSH was combined with $10 \mu \mathrm{M}$ PIA (as in e) then a clear but transient increase in calcium is seen.

TSH, levels of cAMP were high and remained high in the cells for at least $75 \mathrm{~min}$ after the addition.

\section{Discussion}

Investigations of the effect of TSH on intracellular calcium have been largely hampered by the poor reproducibility of the calcium response to TSH in a range of thyroid cells. Also, some of the earlier studies using suspensions of cells (e.g. Rani et al. 1985) only showed increases in calcium in response to relatively high concentrations of TSH, throwing into doubt the physiological relevance of such results. We have previously shown that the concentrations of TSH that increase intracellular calcium in pig cells are 


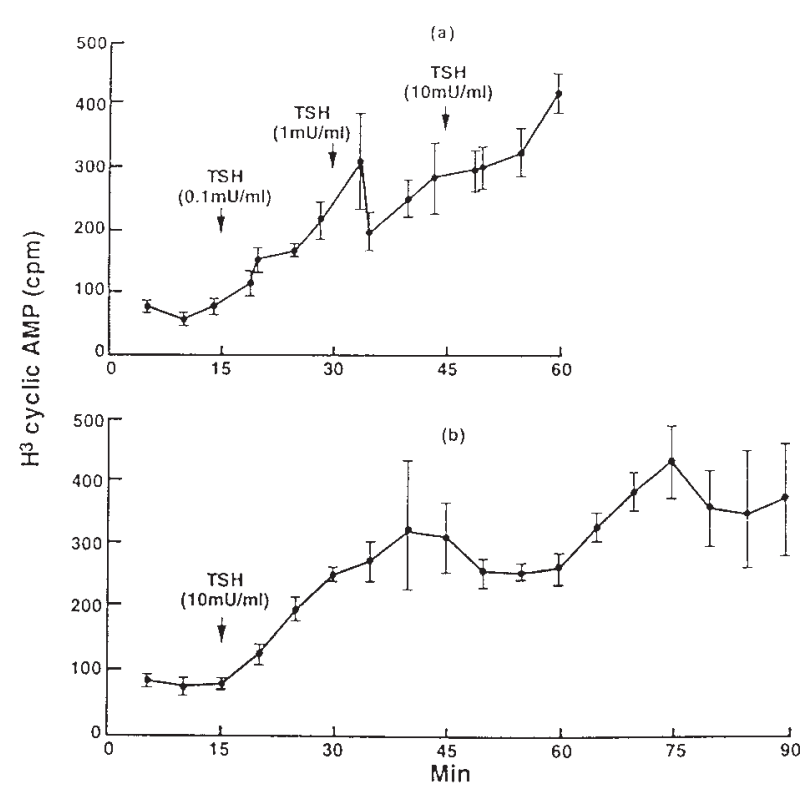

Figure 7 Comparison of the effect of a single addition and repetitive additions of TSH on intracellular CAMP in JPO9 cells. The results shown are the means of four experiments in which cells were exposed to (a) $0 \cdot 1,1$ and $10 \mathrm{mU} / \mathrm{ml}$ at $15 \mathrm{~min}$ intervals or in (b) cells were exposed to $10 \mathrm{mU} / \mathrm{ml} \mathrm{TSH}$ as indicated and intracellular calcium measured throughout the following $75 \mathrm{~min}$.

similar to those that increase cAMP in the same cells $(0 \cdot 1$ to $10 \mathrm{mU} / \mathrm{ml}$ ). However, suspensions of the same cells obtained with trypsin only responded to TSH at much higher concentrations, indicating trypsin-induced damage to the receptor (Ye et al. 1991). We also noted that the concentration of TSH required to elicit an increase in calcium was significantly lower in subconfluent than in confluent thyroid cells, strongly suggesting that the calcium response to TSH might be related to some aspect of thyroid cell proliferation (Ye et al. 1991). Therefore the calcium response to TSH may well have been missed when suspensions or confluent monolayers of cells were used. In JPO9 cells we were particularly interested to note that the calcium response to thyroid-stimulating IgG could be detected at $0 \cdot 1 \mathrm{mg} / \mathrm{ml}$ (18 of 25 Graves' IgGs) and this was less than one-tenth of the concentration required to elicit an increase in cAMP in these cells for these IgGs (Mac Neil et al. 1994).

The aim of the current study was to address the nature and reproducibility of the calcium response to TSH, which we viewed as being important for future studies in this area. A technical problem in the measurement of intracellular calcium in populations of cells (as in our previous studies (Ye et al. 1991, Mac Neil et al. 1994)), is that, unless responses are synchronised for all cells, a small increase in calcium occurring in some cells might not be sufficient to be detected in the whole population of cells. Accordingly, single-cell calcium analysis is preferable, although our own observations had suggested that the poor reproducibility of the TSH-stimulated increase in calcium was a feature of the biology of the cells rather than a problem of detection of such a change. During the course of our initial experiments, after addition of $10 \mathrm{mU} / \mathrm{ml}$ TSH to JPO9 cells, we failed to find any increase in calcium in any single-cell studies. When we adopted a protocol of challenging cells with increasing concentrations of TSH at 5 min intervals, we saw increases in calcium in some, but not all, cells. Similar data were obtained whether calcium was measured in populations of cells or in single cells, i.e. a single challenge with TSH (even at relatively high concentration) was rarely sufficient to induce an increase in calcium; repeated challenges with TSH increased the likelihood of cells responding with an increase in calcium.

Thus this study excludes one of the potential sources of the apparently poor reproducibility of the calcium response, and we show that the method of measuring the calcium response (single-cell calcium analyser or fluorimeter using populations of cells) is, in this context, largely irrelevant to the problem. Use of a single-cell calcium analyser, however, did enable us to look more carefully at the time course of the increase in calcium in response to $\mathrm{TSH}$.

The agonist ATP was used as a positive control for activation of phospholipase $\mathrm{C}$ via $\mathrm{P}_{2}$-purinergic receptors (Sato et al. 1992, Singh et al. 1996). Cells responded to a single addition of ATP with a rapid increase in calcium in the majority $(79 \%)$ of cells challenged. Single exposure to the cholinergic agonist carbachol increased calcium in 32\% of cells. In contrast, none of the cells (40) acutely exposed to $10 \mathrm{mU} / \mathrm{ml} \mathrm{TSH}$ responded with an increase in calcium. Multiple additions of TSH did elicit a response in $27 \%$ of cells (18 of 67). All but one of these cells responded to $1 \mathrm{mU} / \mathrm{ml} \mathrm{TSH}$ with an increase in calcium. However, it was interesting to note that, even then, not all cells within a cluster responded to TSH with an increase in calcium.

We obtained our strongest evidence that the low frequency of calcium response to TSH is a feature of the cell biology rather than a failure of the experimental technique when we looked at the influence of the adenosine derivative PIA on this calcium response to TSH. Whereas responses to either agonist alone were modest, the simultaneous addition of both produced a marked increase in calcium in all monolayers of cells, essentially confirming the cooperativity first reported by Yanagita et al. (1996) for adenosine and TSH in studies on individual human thyroid cells. In their study, the majority of cells (around 80\%) gave a small increase in calcium in response to TSH alone, and this was greatly enhanced by prior addition of PIA. PIA alone produced little or no elevation in calcium concentration but responses to it were similarly enhanced by prior exposure of cells to PIA, illustrating mutual cooperativity in the behaviour of these 
agonists. The action of PIA could be blocked by pertussis toxin treatment, and PIA acted to reduce the TSHstimulated increase in cAMP. Yanagita et al. (1996) speculated that in vivo neural signals may increase the local adenosine concentration (as a breakdown product of the co-transmitter ATP). The authors further pointed out that this may be only part of the picture of modulation of TSH action in vivo.

In exploring the nature of the calcium response to repeated addition of TSH in the current study, we examined to what extent this might relate to the level of cAMP within the cell, as it was feasible that the increase in calcium was not the result of direct activation of phospholipase $\mathrm{C}$ but was, rather, downstream of the effect of TSH on adenylate cyclase and cAMP production. Possibly, the accumulating cAMP was exerting some crosstalk, which ultimately led to an elevation in intracellular calcium concentration. This possibility has previously been explored by ourselves and other workers using forskolin to increase cAMP (Ye et al. 1991, Singh et al. 1996). Both studies concluded that forskolin was unable to mimic the actions of TSH on intracellular calcium (Ye et al. 1991) or inositol phosphate turnover (Singh et al. 1996). In the current study, cells were incubated (in the absence of 3-isobutyl-1-methylxanthine) with either a single addition of TSH $(10 \mathrm{mU} / \mathrm{ml})$ or increasing additions of TSH $(0 \cdot 01$, $0 \cdot 1,1$ and $10 \mathrm{mU} / \mathrm{ml}$ at $5 \mathrm{~min}$ intervals). The level of intracellular cAMP was recorded throughout 60-90 min. These data (Fig. 6) show that, in both cases, there was a rapid and appreciable increase in cAMP, which was sustained throughout the duration of the experiment. A possible explanation may be that the acute addition of $10 \mathrm{mU} / \mathrm{ml} \mathrm{TSH}$ (in the absence of phosphodiesterase inhibitors) might have led to a transient increase in cAMP that was insufficient to promote any action on intracellular calcium. However, our data do not support this hypothesis. Rather, we find there is a significant increase in cAMP to a similar extent in both protocols. This allows us to exclude any link between the level of intracellular cAMP and the effects of TSH on intracellular calcium.

While many studies have concluded or assumed that the effects of TSH on inositol phosphate turnover and calcium are the result of activation of phospholipase $\mathrm{C}$, the kinetics of TSH-induced changes in membrane inositol phosphates do not correspond to those of a classical phospholipase C agonist (Singh et al. 1996). Indeed, data from this laboratory show that, under conditions in which lithium significantly inhibited TSH-stimulated cAMP accumulation in cultured pig cells, there was no hydrolysis of phosphatidylinositol or accumulation of diacylglycerol (Wragg et al. 1993). Thus current evidence does not support an action of TSH on phospholipase C, but instead suggests a slow accumulation of inositol phosphates in response to TSH. The current study suggests that the linkage of the human TSH receptor to whatever enzyme system is causing an increase in calcium is much 'looser' than the linkage between the TSH receptor, G-proteins and the adenylate cyclase enzyme. We suggest that repeat exposure of the receptor to TSH appears to be required for this calcium signal to occur; it was notable that, even under the conditions of our experiments, we did not obtain an increase in calcium in every experiment. The highest frequency we detected was after repeated additions of TSH $(0 \cdot 1,1,10,10,10,10 \mathrm{mU} / \mathrm{ml})$ when 10 of 12 monolayers (83\%) responded to TSH with an increase in calcium. In contrast, 13 of 18 monolayers of the same cells $(72 \%)$ responded to ATP with an increase in calcium after a single addition of ATP. This figure of $83 \%$ is the highest positive frequency we have obtained for TSH stimulation of calcium and was only obtained after repeat exposure to TSH (our previous highest calcium response to TSH was seen in pig thyroid where $77 \%$ of subconfluent cells responded to $10 \mathrm{mU} / \mathrm{ml} \mathrm{TSH}$ with an increase in calcium). Our data showing cooperativity between an adenosine derivative and TSH in elevating calcium concentration strongly suggest that this particular signalling system may be activated in cross-talk situations in vivo.

In summary, although the current study does not identify the mechanism of TSH-induced increases in calcium, it allows us to conclude the following: these increases in calcium are not related to any action of TSH on intracellular cAMP; they can be detected in both single cells and populations of cells; the greatest contributory factor to the achievement of an increase in calcium appears to be multiple exposures of the receptor to TSH. We suggest that this 'loose coupling' of the TSH receptor to the calcium signal may explain why calcium responses to TSH have been so hard to demonstrate in the literature. Possibly, such responses relate to termination of the cAMP-dependent responses to TSH but this remains speculation at present. Certainly, the current study establishes conditions for demonstration of TSH-stimulated increases in intracellular calcium in around $70-80 \%$ of experiments.

\section{Acknowledgements}

The authors are grateful to Professor J E Dumont for the provision of the JPO9 clone.

\section{References}

Berridge MJ, Downs CP \& Hanley MR 1992 Lithium amplifies agonist-dependent phosphatidylinositol response in brain and salivary glands. Biochemical Journal 206 587-595.

Corda D, Marcocci C, Kohn LD, Axelrod J \& Luini A 1985 Association of the changes in cytosolic $\mathrm{Ca}^{2+}$ and iodide efflux induced by thyrotropin and by the stimulation of $\alpha$-adrenergic receptors in cultured rat thyroid cells. Journal of Biological Chemistry 260 9230-9236.

Dumont JE, Maenhaut C \& Lamy F 1992 Control of thyroid-cell proliferation and goitrogenesis. Trends in Endocrinology and Metabolism 3 12-17. 
Lakey T, Mac Neil S, Humphries M, Walker SW, Munro DS \& Tomlinson S 1985 Calcium and calmodulin in the regulation of human thyroid adenylate cyclase activity. Biochemical Journal 225 581-589.

Lazarus JH, John R, Bennie EH, Chalmers RJ \& Crockett G 1981 Lithium therapy and thyroid function: a long term study. Psychological Medicine 11 85-92.

Mac Neil S, Lakey T \& Tomlinson S 1985 Calmodulin regulation of adenylate cyclase activity. Cellular Calcium 6 213-226.

Mac Neil S, Wragg MS, Wagner M \& Tomlinson S 1993 Investigation of the mechanism of lithium-induced hormone resistance. In Lithium in Medicine and Biolog $\gamma$, pp 133-142. Eds NJ Birch, C Padgham, MS Hughes. Carnforth, Lancs: Marius Press.

Mac Neil S, Munro DS, Metcalfe R, Cotterell S, Ruban L, Davies R \& Weetman AP 1994 An investigation of the ability of TSH and Graves' immunoglobulin $G$ to increase intracellular calcium in human thyroid cells, rat FRTL-5 thyroid cells and eukaryotic cells transfected with the human TSH receptor. Journal of Endocrinology 143 527-540.

Michelangeli VP, Munro DS, Poon CW, Frauman AG \& Colman PG 1994 Measurement of thyroid stimulating immunoglobulins in a new cell line transfected with a functional human TSH receptor (JPO9 cells) compared with an assay using FRTL-5 cells. Clinical Endocrinology 40 645-652.

Mori M, Tajima K, Ode Y, Matsui I, Mashita K \& Tarui S 1989 Inhibitory effect of lithium on the release of thyroid hormones from thyrotropin-stimulated mouse thyroids in a perfusion system. Endocrinology 124 1365-1369.

Rani CSS, Boyd AE \& Field JB 1985 Effects of acetylcholine, TSH and other stimulators on intracellular calcium concentration in $\operatorname{dog}$ thyroid cells. Biochemical and Biophysical Research Communications 131 1041-1047.

Sato K, Okajima F \& Kando Y 1992 Extracellular ATP stimulates three different receptor-signal transduction systems in FRTL5 thyroid cells Activation of phospholipase $\mathrm{C}$ and inhibition and activation of adenylate cyclase. Biochemical Journal 283 281-287.

Scott TW, Freinkel N, Klein JH \& Nitzan M 1970 Metabolism of phospholipids, neutralipids and carbohydrates in dispersed porcine thyroid cells: comparative effect of thyrotropin and dibutyryl $3^{\prime}, 5^{\prime}$-adenosine monophosphate on the turnover of phospholipids in insolated cells from pig thyroid. Endocrinology 87 854-863.

Shuman SJ, Zor U, Chayoth R \& Field JB 1976 Exposure of thyroid slides to thyroid-stimulating hormone induces refractoriness of the
cAMP system to subsequent hormone stimulation. Journal of Clinical Investigation $\mathbf{5 7}$ 1132-1141.

Singh J, Hunt P, Eggo MC, Sheppard MC, Kirk CJ \& Michell RH 1996 Thyroid-stimulating hormone rapidly stimulates inositol polyphosphate formation in FRTL-5 thyrocytes without activating phosphoinositidase C. Biochemical Journal 316 175-182.

Takasu N, Yamauchi K, Katakura M, Yamada T \& Shimizu Y 1986 TSH stimulated increases in calcium uptake and calmodulin level in thyroid cells. Biochemical and Biophysical Research Communications 136 306-309.

Takasu N, Yamada T \& Shimizu Y 1988 Thyrotrophin and prostaglandin $\mathrm{E}_{2}$ increase calmodulin levels and cAMP phosphodiesterase activity in cultured porcine thyroid cells. Journal of Endocrinology 117 109-114.

Van Sande J, Raspe E, Perret J, Lejeune C, Maenhaut C, Vassart G \& Dumont JE 1990 Thyrotropin activates both the cyclic AMP and the $\mathrm{PIP}_{2}$ cascades in $\mathrm{CHO}$ cells expressing the human cDNA of TSH receptor. Molecular and Cellular Endocrinology 74 R1-R6.

Weiss SJ, Philip NJ \& Grollman EF 1984 Effect of thyrotropin on iodide efflux in FRTL-5 cells mediated by $\mathrm{Ca}^{2+}$. Endocrinology 114 1108-1113.

Williams JA, Berens SC \& Wolff J 1971 Thyroid secretion in vitro: inhibition of TSH and dibutyryl cyclic AMP stimulated ${ }^{131} \mathrm{I}$ release by lithium. Endocrinology 88 1385-1388.

Wragg MS \& Mac Neil S 1991 Inhibitory effect of lithium on basal and agonist stimulated cAMP accumulation in porcine thyroid tissue: a potential model of lithium-induced hypothyroidism. Lithium 2 1-10.

Wragg MS, Metcalfe RA, Dobson PRM, Brown BL \& Mac Neil S 1993 Investigation of lithium-induced TSH resistance in porcine thyroid cells; effects of lithium on TSH binding and on phosphatidylinositol signalling system. Lithium 4 95-107.

Yanagita Y, Okujima F, Sho K, Nagamachi Y \& Kondo Y 1996 An adenosine derivative cooperates with TSH and Graves' IgG to induce calcium mobilisation in single human thyroid cells. Molecular and Cellular Endocrinology 118 47-56.

Ye QL, Wagner M, Smythe S \& Mac Neil S 1991 Thyrotrophin, but not forskolin, increases intracellular free calcium and calmodulin in pig thyroid cells. Journal of Endocrinology 129 291-299.

Received 24 June 1997

Revised manuscript received 7 January 1998 Accepted 2 February 1998 